Nalar: Jurnal Peradaban dan Pemikiran Islam

Volume 4 Nomor 1, Juni 2020

http://e-journal.iain-palangkaraya.ac.id/index.php/nalar

E-ISSN: 2598-8999, P-ISSN: 2597-9930

\title{
Treating Religious Differences: Hikmah Muta'aliyah as An Alternative to Ethical Crisis in Contemporary Era
}

\author{
Nurul Khair ${ }^{1 *}$, Muhammad Thaha \\ ${ }^{1}$ Ablul Bait International University, Tebran, Iran \\ ${ }^{2}$ Ablul Bait International University, Tebran, Iran \\ *nurulkhair97@gmail.com
}

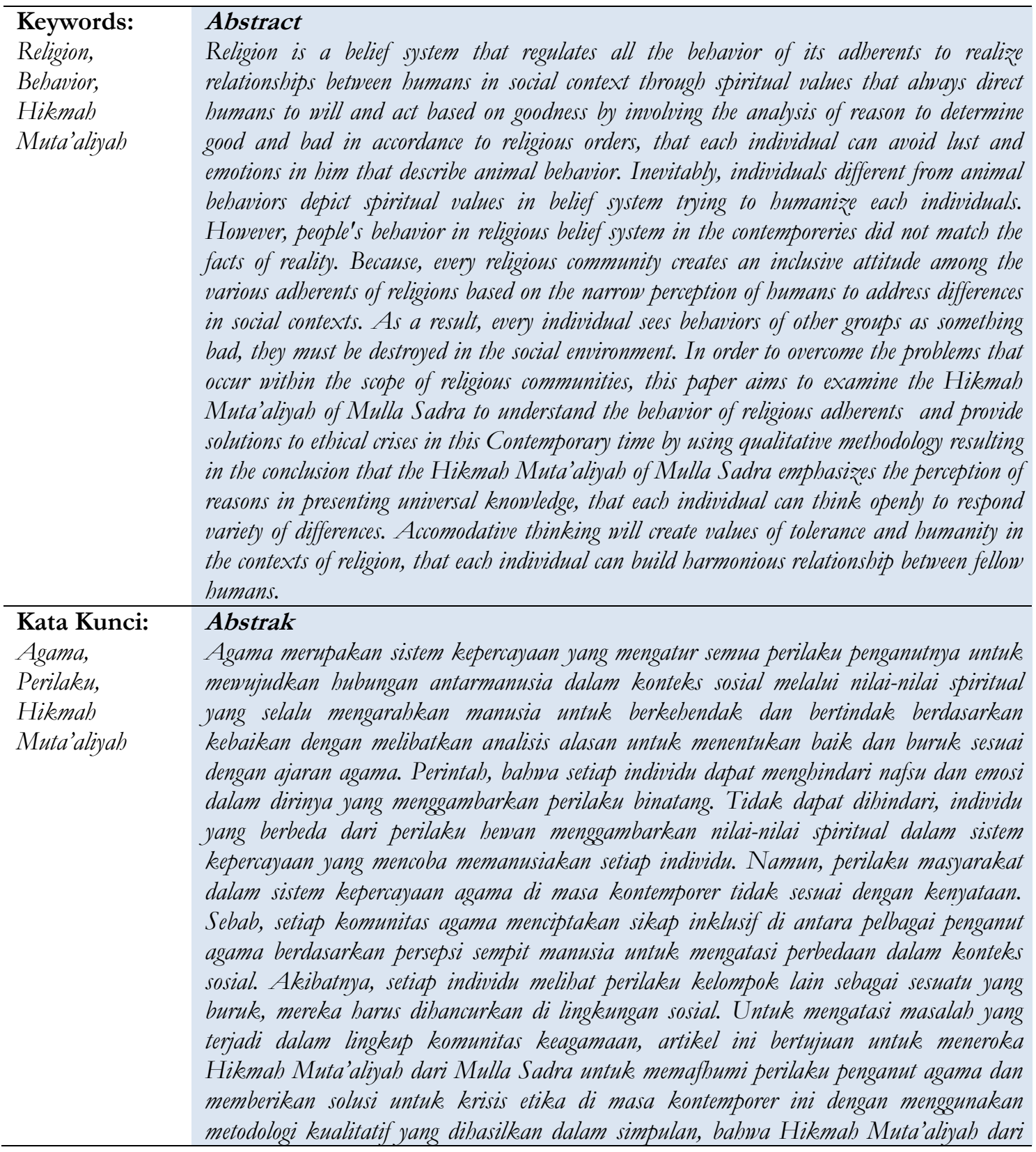




\begin{tabular}{ll}
\hline Mulla Sadra menekankan persepsi alasan dalam menyajikan pengetahuan universal, bahwa \\
setiap individu dapat berpikir secara terbuka untuk merespon pelbagai perbedaan. \\
Pemikiran akomodatif akan menciptakan nilai-nilai toleransi dan kemanusiaan dalam \\
kenteks agama, bahwa setiap individu dapat membangun bubungan yang harmonis antara \\
sesama manusia.
\end{tabular}

\section{INTRODUCTION}

Religion in social context view as system which control every individual acts and deeds to create a harmonious relation between being as such. Realization of harmonious relation between beings is the effort to getting themselves to God, which viewed as each vision of human life in the world, so that religion has the urgency to realise every vision of individual through systems which applied in social context (Nur 2016). In sociological discourse, it is known that some figures has analysed the urgency of religion for human life, like Emile Durkheim (2011), explaining about the important role of religion for society, is to create the closeness between one another, without looking at any tribe, race, and skin color and view as something accidental in human's lifes.

According to Emile Durkheim, differences experienced by individuals based on worldly experiences or we call it as profane has created gap between fellow beings that do not pay attention to each other's lives. For instance, individual $\mathbf{A}$ works as a trader and individual $\mathbf{B}$ works as a fisherman. The two of them have never met; they have never even looked at each other's lives which are seen as social inequalities. Emile Durkheim views that religion functions to unite and bring individual closer to another as the image or image of religion as a place of harmonization (Marzali 2017).

Emile Durkheim's views are confirmed by Huston Smith (2015), explains that religion is both hope and goal for each individual to express various creativity to bring his existence closer to God is seen as the existence of the Most Perfect in reality. The term Perfect in Huston Smith (2015) view is the source of perfection, which is permanent and universal. Logically, human beings wanted a perfection which is permanent and universal in his lives. Religion has it scope to explain about the meaning of perfection which is permanent and universal to human through certain system which applies in social contexts.

Based on many explanations above, it can be understood that religion has the urgency to harmonize individual existence or between being and another as the process of his closeness to God to achieve perfection in reality. In contemporary era, religion gain special attention in the paradigm of society with the opening of religious studies through social media approaches. Social media is a place which uses by religious leader and societies to achieving knowledge toward religious teaching. Nonetheless, the using of social media as the place for religious preaching gives two implications to religious societies nowadays.

First, there are inequalities. It is known that religious information come online by involving social media, such as Youtube, Instagram, and What'sapp, and it implies the gap between individuals. The implications are, harmonization among religious communities has declined. Second, the creation of particular paradigm, because religious communities are tend to accept information limitedly. Limited information tend to be used by individual to build their knowledge to get closer to God and looked at other knowledge beside it as something that is distorted and misguided, as been known that the development of the practice of radicalism is based on particular paradigm as the process to get them closer to God (Asrori 2015).

From the above problem, we can see that it has influence the practice of extremism to rejects and limits other people beliefs in the context of religious communities to get closer to God. One of the concrete prove that we can feel today, is that the higher level of 
violence between religious people, as the National Committee (Komisi Nasional) noted that the increase of violence case and limitation of the belief of religious people for the last three years. In 2014, KOMNAS HAM (National Committee of Human Rights) has listed about 74 cases on the violance of religious people in the whole regions of Indonesia. Those numbers are increasing in 2015, for about 87 cases. In 2016 gets increases about 97 cases (Komnas HAM 2017).

The higher level of violence and limitation of beliefs among religious societies are also emphasized by the Wahid Institute (2016) in the research under the title Kemerdekaan Beragama Berkeyakinan (KBB) that there has been increasing of KBB violation for the last three years. In 2014, Wahid Foundation listed there are 158 cases. Then in 2015 increases into 20\% about 190 cases. Next, in 2016 there's about 204 cases.

Whereas, Hikam and Riyanta (2018) in their research on the title Development of Radical groups in Indonesia Post Goverment Regulations in Liue of Law no. 2/2017 Regarding Community Organization and Law no 5/2018 Regarding Terrorism in National Secuarity Perspective said that theres about 1.494 cases of violation and religious intolerance for 18 years, from 2000 until 2018. According to Muhammad AS Hikam and Stanislaus Riyanta, the higher case of violence and religious intolerance is based on doctrinal understanding toward religious beliefs in individual paradigm, which describes exclusivism thinking pattern.

From the above datas, it is known that religious violant behavior and limitation of beliefs are the main problem in the life of contemporary societies that causes gap among individuals to build harmonization as a process of existential perfection in reality. The behavior of violence and religious limitation was based on particular paradigm of society in viewing religiousity in reality, so they are tend to see reality based on one perspective. As a result, something different with their knowledge are seen as something that deviates (Mutahhari 1978).

On the other side, the main problem is the appearance of particular paradigm that based on dogmatical behavior of religious communities who takes any information accepted through social media without further review and study about that true information, so that each individual has created exclusive behavior in his lives. This exclusive behavior will bring about intolerant and extremist behavior in the individual itself which causes him to do violent and limitation of belief of other individuals. Consequently, each individual will limit themselves and do violate act between one another. The implication is religions are seen as harmonization place among beings through systemic rules which not realized as it is.

The root of the particular paradigm was background by the development of secular paradigm which views all validities of information into three principle, they are, measurable, light and systematic (Bennet 2001). Measurable means something or object is made up of three-dimensional elements, it covers long, wide and tall. While, the supernatural is the object to be perceived through human sense perception. Whereas, systematic means that the order of human perception is based on the driving force, which are desire and emotion. The thord principles commonly called as scientific method (Capoleston 1985).

Those three secular principles are directing religious communities into a more particular sense to build their religious understanding through scientific approaches. To deal with those many problems, we need solution as a form of attention toward ethical crisis of religious community in the contemporary era are viewed to be has losing its existence in reality (Mandaling 2013). Based on the research, it can be known that religious community behavior has describes degradation of his own existence which influence by 
desire and emotion, so that we need existential approaches that discuss human existence as the object.

In Islamic Philosophical Civilization, it is known that human existence studied through existential approach to know the essence of human existence (Rizvi 2009). One of the Islamic philosophical orders study and discuss human existence, which is Mulla Sadra's Hikmah Muta'aliyah. Mulla Sadra study human existence through some theme which view as principle of human perfection, such as harakah al-jauhariyah, the essence of knowledge, various being, and al'aql al-munawar.

The theme harakab al-jaubariyah explain that human soul experience perfect movement from potential phase (the ability to be perfect) into actual phase (perfect) by involving all perception force in himself. It means, human are demanded to optimalize all the potention of perception in him, covering sensory perception and reason. Human being who's counting on sense perception tends to achieve particular knowledge. Particular knowledge implies the rise of imagination influenced by emotion that moves will and human behavior in reality. Behavior reflects by emotion tend to looking for desire in it's existence, as a result human existence viewed as animal that moved into will to desire and emotion (Khatoon 2004). Whereas, human is on rational phase, level of highest soul, has potentiality to obtain universal knowledge which describes the perfection of reason. Perfection of reason (al-'aql munawar) will guide human paradigm to view something logically by considering happiness and peace based on good behavior, so that human can build harmony between beings to perfecting themselves and getting closer to God in reality (Kalbikani 1998).

Based on various explanations above, it can be known that Mulla Sadra's Hikmah Muta'aliyah is a wise solution to ease particular paradigm and intolerance in the life of religious people. On the one hand, Mulla Sadra's Hikmah Muta'aliyah as the alternative to ease ethical crisis in the lives of religious communities that viewed has experience many problems in facing the difference in the scope of religion.

This article is trying to study and discusses about Mulla Sadra's Hikmat Muta'aliyah through his magnum opus, al-Hikmah al-Mutäliyah fì al-Asfär al-Aqliyyah al-Arba'ah on the purpose to preserve unity between religious people through the perfection of reason as the instrument of human knowledge. In order to achieve this purpose, this paper requires a methodology that explains the collection and analysis of primary source data. In the research methodology discourse, there are two type of research, namely qualitative and quantitave. Qualitative explain how to describe and analyze data through a theoretical foundation approach based on the primary source data. Meanwhile, quantitave explain how to analyze data through a numerical approach (Ali 2011).

In this article, using qualitative approach as methodology that refers to primary and secondary sources in data collection. Primary sources in article, is al-Hikmah al-Mutäliyah $f i$ al- Asfär al-Aqliyyah al-Arba'ah to understand the urgency "Hikmah Muta'aliyah as An Alternative to Ethical Crisis in Contemporary Era". Meanwhile, secondary data in this paper are books, journals, and theses that discuss Mulla Sadra's philosophy. Primary and secondary data are analyzed and interpreted by the problem of ethical crisis and solution Hikmah Muta'aliyah (Chumaedi 2018).

The results of the analysis and interpretation explain that humans have reason is the highest faculty of soul that place reason to perceived the object of knowledge universally through the process of abstraction. The abstraction process of reason necessitates a universal knowledge so that each individual can think openly which influence all the act and paradigms in understanding religiosity as one of the attitudes of caring for religious unity in social context. 
Moreover, this paper ini is a new offering in studying human existence in Mulla Sadra view which reviewed through his masterpiece al-Hikmah al-Mutäliyah fì al-Asfär alAqliyyah al-Arba'ah which is presented through some ontological and epistemological teaching of Mulla Sadra. It is different with the research done by Happy Saputra (2016) in his research under the title "Konsep Epistemologi Mulla Sadra" published in the Jurnal Substantia who examined Mulla Sadra's thoughts. As well as what Sholihan(2010) did in her research under the title "Al-Hikmah al-Muta'aliyah: Pemikiran Metafisik Eksistensialistik Mulla Sadra" which do not directly refer to Mulla Sadra magnum opus which is seen as unable to represent Mulla Sadra's view comprehensively.

Whereas, the research which done by Dudi Badruzaman (2019) on the title Paradigma Epistemologi Filsafat Islam in author view, has not yet bring out and explains some teachings of Mulla Sadra in the study of epistemology so that it needed a further research that will explains about Mulla Sadra's teachings in the field of epistemology related to ethical perfectionand human paradigm. In that case, it can be known that this article is trying to serve Mulla Sadra's view point as moral crisis alternatives in the contemporary era to perfecting the previous research and also as the new point of view in understanding the human existence.

\section{RESULT AND DISCUSSION}

\section{The Principle of Hikmah Muta'aliyah on Human Existence}

Mulla Sadra in al-Hikmah al-Mutäliyah fì al-Asfär al-Aqliyyah al-Arba'ah explain that the main principle of Hikmah al-Mutāliyah, is the perfection of human existence that can be achieved through some themes, such as harakah al-jaubariyah discusses about movement of perfection of soul. According to Mulla Sadra, soul is human identity which always having perfection through correspondency of reason and sense perception to gained the essence of knowledge (Rezai 1999). The essence of knowledge will guide human soul to move from potential phase into actual. In the process of activity of soul, human will going through many faculties of knowledge of the soul, they are plant and animal faculty that view that every object of knowledge based on desire and emotion toward the highest existence, that is faculty of reason (Walid 2012).

Human who has reached faculty of reason will know everything based on the right paradigm as the perfection of the soul of the known. The perfection of paradigm will affect human behavior to do well, because all good behavior is coming from true paradigm as the image of perfection theoretically and practically (Sadra 1941). Thus, it can be known that the relation of Mulla Sadra's principles and teachings are related to the problem of the perfection of human existence. In order to make clear the discussion, author will explains about each theme separatedly, in order to give a comprehensive explanation. Here are the explanations as follows.

\section{Harakat al-Jauhariyah}

Harakat al-jaubariyah was one important discussion in Islamic philosophy which backgrounds by the view of the ashälatul wujud philosophers who believes in changes or movement in existence of an enity in reality (Eshots 2010). The understanding of the ashälatul wujüd philosophers toward the movement of an entity was influenced by Aristotles thought on the tenth categories. The ashälatul wujüd philosophers has two different view points in facing Aristotle's 10 categories, which consists of 9 categories of accidents (something that can be perceived by senses, such as color, shape and height) and 1 substantial category (which cannot perceived by senses, like soul for instance). 
The first view, believe on the four of the tenth categories of Aristotle. The first view was dominated by peripathetic philosopher, like Ibn Sina who view that changes, movements, of the movement of entity is affected by certain categories, quantity, quality, place and position. Based on those four categories, it can be known that the most certain place moved and changed from one position into another, Bsuch as the movement of the $\mathrm{x}$ car from position a into position b (Eshots 2010).

Whereas another categories, such as quantity can be seen through the groeth of human body from the child phase to teenager phase. Man growth from children phase to teenager phase describes the displacement or movement of quantity in human existence (accidental movement). In another case, it can be known that the color of raw apple in green color changed into ripe apple in pink colorthe changes of the apple is not only happen to only color, but the changes of taste from tasteless into sweet. The changes of an apple, whether from taste to color is also called as the movement of quality in philosophical term.

Peripatetic philosophers view the displacement or movement in position and quality happen to accidental and material aspects. Second view, dominated by the Hikmah al-Muta'aliyah philosophers, such as Mulla Sadra believe in five categories, consists of four accidental categories, which are quality, quantity, space and time. Whereas, another one category is substantial which view on the whole changes, movement or displacement of entity based on substance. And accident is something hanging on substance existentially to move in reality (Haq 2013).

Mulla Sadra gives argumentation to prove that movement occurs in substance. First argumentation, describes the existence of substance (soul) as the mover to any categorical changes of accident in reality. Substance are always reflecting accidental category to experience changes and displacement in reality. Accidental category cannot experience changes without the influence of substance in reality. For example, human body do not experience growth without influenced by the existence of soul (Khamaeni 2004).

Second Argumentation, Mulla Sadra study about substance and accident through cause-effect approach (soul as the cause that moves matter). According to Mulla Sadra, substance is the cause for accident to move in reality (Khamenei 2004). Third argumentation, that substance is eternal and accident is limited. Mulla Sadra studying substantial and accidental matter through the approach of kaun wa al-fasad (genesis and destruction). According to Mulla Sadra, substance (soul) are kaun (will rise again after from the human body) and accident are fasad (destroy within the human body). Substance will rise again toward the process of perfection. The rise of substance toward the process of perfection describes becoming (the process of perfection through perfect movement) (Hossein and Mansur 2009).

Becoming is one of the terms in philosophy uses to desrcribe the process of perfection and eternality of existence gradually. As for the accident experienced destruction describing its existence is limited (Kamal 2009). The awakening of substance in Mulla Sadra's view is based on the existence of the soul is seen as something metaphysical that experiences a gradual movement in accordance with its actuality by involving the perfection of reason. That is, the actuality of the human soul depends on the perfection of reason (Rezai 1999). To make clear the urgency of reason to human existence, so this paper will explain about the discourse of knowledge in philosophical civilization in the next discussion.

\section{The Essence of Knowledge}

The concept of the essence of knowledge is a serious discourse in the development of philosophy which background by many perspective of philosopher about the process of 
the existence of knowledge in human self (Reza 1999). Historically, there are three perspectives on the discourse of knowledge in human lifes (Bartens 2005). First perspective, is majority of empirism, like David Hume who view sensory perception is the source of knowledge for human beings to know and understand the entity of reality, for example: Individual are able to know the existence of chair, table, and window based on his vision or it can be said Ahmad able to smell the fragrance of a perfume and the smell the trash through his sense of smell (Russell 2016; Hadiwijono 1980; Palmer 2001).

Second view, is the majority of rationalism, like Rene Descartes who view that reason as the source of knowledge to know the existent of the object perception through conception process (Hardiman 2004; Copleston 1985). Rationalist are also view that reason can perceive immaterial entity, like the soul by involving the process of conseption. Conception of reason is universal, so that each individual able to know the existence of soul in human body as one of core identity of its existence in reality. Human knowledge about the existence of the soul describes reason as the source of knowledge in reality (Labib 2011).

Third views, is the majority of the sophist (the school who reject Greek philosophy in Socrates era) viewed that the source of knowledge is something impossible in human beings. The sophist views that there is no essence of reality, whether material or immaterial in reality (Russell 2016; Copleston 1985). As a result, human beings are not able to recognize everything outside his existence. Implication is human being does not have source of knowledge, whether material or immaterial in himself. The sophist necessitates that there is no essence of knowledge in human life. Because, all entity of reality are illusion or mirage in human lives (Palmer 2001).

Various views of philosophers concerning source of knowledge affecting Mulla Sadra thought in studying and discussing the essence of knowledge in human beings. According to him, the essence of knowledge is the existence of something inside human essentially, as human beings acknowledge his existence directly or necessarily without abstraction of reason or sense perception in reality (Sadra 1984). Thabathabai in his book Bidayah al-Hikhmah describes knowledge like a baby sucking milk between his mother's breasts. He did not have the experience or rational abstraction to understand how to suck milk well, but the baby necessarily know it (Sayyed Hossein Thabathabai 1997).

Though the essence of knowledge is necessity, it need to know that Mulla Sadra never ignoring the abstraction of reason as one of instrument of knowledge. According to Mulla Sadra, human reason has the faculty of perception to guide human to reach the essence of knowledge in relaity (Sayyid Husain Thabathabai 2000). Mulla Sadra explains that the ability of reason as human guide on the theme aql al-munawar which will be explain by the author in the next discussion.

\section{Aq1 Munawar as the Source of Human Knowledge}

The theme of aql munawar is one theme which develop by Mulla Sadra to prove the existential of reason as the source of human knowledge which background by the view of some Muslim philosopher before Mulla Sadra, like Al-Farabi and Ibn Sina do not believe on the concept of unity of subject (the thinking individual) and object (something in mind) (ittihäd àql wa ma'qül) in human beings as impossibility. The impossible unity of subjectobject is based on perceptional faculty of subject in obtaining quiddity (something known through sense perception and rational analysis) of object which abstract by reason before sensed by sensory perception in reality (Kalin 2010).

The production of reason toward quiddity of object resulting universal concept that create renewal of object quantity in reality, example: When A (subject) unite with B (object) 
resulting $\mathrm{C}$ (synthesis between $\mathrm{A}$ and $\mathrm{B}$ ). $\mathrm{C}$ is diferent transformation from $\mathrm{A}$ and $\mathrm{B}$. The result is, the identity of $\mathrm{C}$ is different with the first identity, that is $\mathrm{A}$ and $\mathrm{B}$. According to Ibn Sina, it is impossible for $\mathrm{C}$ to leave its real identity, that is $\mathrm{A}$ and $\mathrm{B}$. If $\mathrm{C}$ leaved its real identity, so it causes substantial differences between $\mathrm{C}$ and $\mathrm{A}$, and $\mathrm{B}$ as a constituent (Kalin 2010).

Mulla Sadra overcoming the mistakes of peripatetic philosophers through the theme of ittihäd āql wa ma'qül that human being acknowledge two dimensional knowledge, external and mental. External knowledge-there are wujud khariji (something perceived by sense perception-and menta-there is also wujud dribini (concept or idea)-that must have correspondency to obtain the truth of perceptional object in reality. If human has obtained the truth of an object, so that he can differentiate between essence and non essence of something in relity. The correspondency of mental and external knowledge, the more human beings obtained the truth of reality.

Correspondency of mental (dzihni) and external eksternal (khariji) knowledge can be achieved by the unity of the subject as the knower, object as the known and reason as the meeting media between subject and object. Human mind will abstracts everything is known by the subject toward object to produce a universal concept as the process of rational perfection finding truth in reality (Khamenei 2004).

Concept of ittibäd äql wa ma'qül are stated by Mulla Sadra in the discussion of ma'qulat (universal conceptions) that all knowledge that obtained by human are coming from ma'qulat al-awwali by involving sense perception. Sense perception force is the main bridge for the objects of knowledge to go through the abstractional process of human mind (Kamal 1988). Abstraction process of human are called as ma'qulat at- tsani falsafi having coherency (suitability) between meltal realm and external reality, so that human are not fail to know the existence of perceptional objects through the unity of two scopes of knowledge in reality (Khamaeni 2004).

The unity of the scope of knowledge influenced by human awareness knowing the existential being drihni and khariji which influence human paradigm to differentiate and understand something essential and non-essential based on being as the source effect in reality (Mousavi 1999). Human knowledge toward the essence of reality based on the existential reason that can realize two dimension of knowledge which correspond between one another. Correspondency of two dimensions creates activity of reason to produce a universal concept that applied based on fact of reality (Sayyed Hossein Thabathabai 2000).

The fact of reality influences the process of prediction between two universal concepts that has relation totally or partly. All activity of reason about two dimensional awareness, two dimensional unities, the process of universal concept production, and prediction of two universal concepts has causing actual faculty of human mind to realize the true reality (Kalbikani 1998). Mulla Sadra explain about the actuality of rational faculty in the theme of akal munawar or al-aql al-fa'al (active mind) influenced the actuality of soul as the knowing substance. Mulla Sadra view that all knowledge sense by human beings are sourced from the soul that moves all the human will and mind in reality (Mousavi 1999). Will and mind of individual will describes the existential soul, as been explained that the soul has level or varieties in human beings.

\section{Variety of Human Beings}

The concept of man is one of the discussions that discuss by Muslim thinkers to prove transcendental perfection (something eternal) in human self. Some of Muslim thinkers, sucah as Al-Farabi and Ibn Sina study and discuss about transcendental perfection through the existential of soul as the first perfection of human body. The meaning of the 
first perfection to body in Al-Farabi (1976) view is human physical cannot act and think without the influence of soul. Al-Farabi's view is in accordance with the thought of Ibn Sina (1952) in his work Ahwal al-Nafs that soul is the first perfection, because every species (jins) becomes perfect through the influence of soul.

All Muslim thinkers, before Mulla Sadra describes the existence of soul as something necessary in human beings. It means, human are able to understood the existence of soul, so that he is able to recognize the perfect potential of himself in reality. The potential of perfect soul in human body describes human core substance have many levels, as it actual level in reality (Fazlurrahman 2000). Muslim thinkers, divide three levels of the soul based on its actualization, that is plants soul, animal soul and human soul (AlGhazali 1975).

Al-Farabi (1976) in his book explains that from those three levels, the plant soul is the lowest level in human self. Because, if plantation soul involving nutrition, growth, and breed (natural attribute of plants) to perfectized itself in reality. According to al-Farabi, man who's life are only to eat and to breed describes it existential soul are in the level of plantation, as Ibn Sina view (Najati 2002).

Whereas animal soul, al-Farabi or we call him as al-mu'alim al-tsani (second teacher) explain that individual ability to perceive entity in reality based on the ability of sense perception in reality. Meaning, animal soul has additional mechanism rather than plant soul only limibted in finding nutrition and to breed. According to al-Farabi, animal soul can reflect man to know something beside himself through the five senses (every animal has five senses to perceive something outside himself) (Najati 2002). Human beings based on the five senses are particular, so that the individual understanding toward entity are limited that depends on the reach of sensory perception.

On the other side, al-Farabi (1976) explain that the process of sense perception affecting human imagination faculty, so that every image captured by the five sense resulting image in human mental. The image of object in mental is particular, as the reach of the five senses as partials. Example: Individual sees a red car in front of STFI Sadra. The perception toward the red car is brought into mental realm, so that the knowledge toward the red car exist in his knowledge about the car in red color, limited to the appearance of reality without the process of analysis concerning the existence of car as subject and red as predicate.

Ibn Sina is different with al-Farabi understanding on animal soul that if al-mu'alim al-tsani understand the soul only in particular knowledge which influence individual imagination, so Ibn Sina view that human sense perception are influenced by the moving faculty in himself, like desire and anger. Ibn Sina (1952) views that the ability of human sensory perception is mechanically. It means that, the faculty of sense perception cannot be actualized without moved by his desire toward the entity of reality. Human has the interest toward something outside himself which is material, so that they view that the existence is based on sensory perception.

Since, emotional faculty is the ability of human being to fight and avoiding everything that consider as endanger its existence in reality. For example: when a man sees a snake in the middle of the forest. By reflects, he realized that the existence of the snake has endangered his lives, so he do rebellion to save his existence in reality. Human reflection toward snake endanger himself will bring knowledge to avoid the existence of the snake in the future (Najati 2002).

Eventhough, Ibn Sina and al-Farabi has different view point on the level of animal in human soul, but both are having the same view about the level of reason as the highest soul affecting human perfection within two sides, that is theoretical and practical 
(Rahmatiah 2018). Theoretically, reason has influence human paradigms to analyze everything critically, so that each individual can apprehend the truth of existential entity of reality based on right or wrong. Human truth in understanding the entity of reality affecting human action in reality (Sina 1998).

For, it is known that every single individual is move based on his knowledge, as the Muslim thinker view that the soul is the first perfection of human physical body mechanistically and systematically (Gama 2018). Ibn Sina and Al-Farabi view was perfectized by Mulla Sadra through the theme of substantial motion to prove that there is movement of soul toward perfection through unity of reason and sensory perception faculties. Mulla Sadra explains about the cooperation between reason and sensory perception through the theme of ma'qulat that the sensory perception is the first gate for human beings to know about the existence of entity of reality (Kalin 2000).

Mulla Sadra said that the process of sensory perception is called as ma'qulat alawwali. Then, sensory perception is change into particular image in mental realm. Particular image is brought to reason to be analyzed, so that the result of reason analysis is universal (Sayyed Hossein Thabathabai 2011). Mulla Sadra mention about the process of the changing image from particular into universal through analysis of reason by the term ma'qulat al-tsani al-falsafi. The result of rational analysis affecting two aspects in human body, which is al-ma'rifat al-baq (theoretics) and al-ma'rifat al-khair (practics) (Rezai 1999). Theoretical and practical influence describes holistical perfection, whether in action or paradigm in human body. The influence of reason toward holistical perfection will be explains in the following chapter.

\section{Holistical Perfection}

The holistical perfection theme in this writing is one of the next discussions on the unity of the sense perception and reason to actualize the existence of the soul in human in Mulla Sadra perspectives. On the previous discussion, it has been explain that sense perfection is the first gate to produce particular image that send toward reason to be analyse and verify its validity. The results of rational verification will result universal images and correspondence of two domains of knowledges, which is external (khariji) and internal (dribni) (Khamenei 2004).

Correspondency of two domain of knowledge will influence the actuality of human soul. The actuality of reason influenced the existence of human soul, because reason is the highest faculty of soul influencing attribution of soul-knowledge-that influence simplicity (basith) of human soul through the process of perception of something in reality (Sayyed Hossein Thabathabai 2000). The simplicity of soul describes the perfection of paradigm and human attitude in the world through two aspects, that is theoretical and practical based on its actual pattern in reality (Sina 1998). Theoretical perfection is the knowledge of human reason to understand the whole object of reality, somthat he perceive everything through truth to know the essence of reality.

Theoretical perfection can be describes through ma'rifat al-haq (knowledge of truth) influencing human paradigm to analyze and think of everything based on reason. Human reason is the wheel to activate all the chains of human acts based on his perception toward reality (Sina 1960). Perception toward reality will create knowledge, so that human can act based on his knowledge. Human achieve ma'rifat al-haq and act logically and systematically by ignoring their desire and emotion in each will (Miri 2005). It means that, man act based on his understanding through his process of awareness toward object of reality.

The awareness to act actualizes human ethical view to know the good (ma'rifat alkhair). Ma'rifat al-khair describes the perfection of human ethics to act based on the 
goodness by neglecting all evil (Sadra 2002). Human knowledge toward something good are based on the power of human soul to analyze something bad and good by involving actualization of human reason which describe through ma'rifat al-haq (Sina 1998).

Sayyid Kamal Haidari was one of Mulla Sadra commentators, explaining on how to reach the perfection of theoretical and practical reason in the book Bubusun fi Tlmi al-Nafs al-Falsafi that the main step to actualizes ma'rifat al-haq through external knowledge as something basic. Sayyid Kamal Haidari (2011) explain that human knowledge perceived through individual interaction with external to get information based on the sensory stimulation, whether hearing, vision, and stimuli. Sayyid Kamal Haidar said that sensory knowledge with the term al-aql al-haynila as the lower level in ma'rifat al-haq.

Furthermore, Sayyid Kamal Haidari explain that individual knowledge on external object must be practice through act to create habits, like someone knowledge about honesty is good, so that he must practice an honest behavior as the basic knowledge obtained by reason. According to Sayyid Kamal Haidari, if individual acustomed himself to act orderly with knowledge al-aql al-baynla will create habitation that is embedded in human body which called as al-aql al-malakah (Haidari 2011; Sadra 2002).

Al-aql al-malakab is the second level of reason which describes the incorporation of knowledge into the human body into a daily routine. The practice of the individual toact on his knowledge restricts the presence of al-aql al-fi'il as the third stage of the epistemological realm that describes the correspondence between mental knowledge and human action to achieve the truth. On the level of al-aql al-fi'il, the existence of human soul experiences simplicity based on the practice of knowledge practice in its action (Sadra 2002).

Sayyid Kamal Haidari also explain that the level of al-aql al-fi'il is the result of decoration or takhalli in humen beings by involving al-aql al-malakah as the main basis of human in perfecting his soul in reality (Haidari 2011). The process of correspondency between mental and eksternal, also takballi will necessitates the level of human reason toward al-aql al-mustafät through the process of tajalli in human self. Al-aql al-mustafät is the highest reason in the ordain of ma'rifat al-haq which influence each individual to view everything based on its true knowledge, so that they have the true attributes in themselves (Sadra 1984).

The attribution of the truth will affect human action that describes human existence identically with His existence. It means that individual that has reach the level of al-aql al-mustafät will reflect their attributes as His attribute and their acts as His acts in reality (Haq 2013). The disclosure or the reflection of His existence in human body as the process of mortal or destructive to the material realm as a reflection of the divine values of the human being arising or the existence of the human soul in order to actually lead to the increase of existence through the manner of the journey of the soul to perfection (Haidari 2011).

\section{Analysis}

The main problem for the creation of violence and intolerance in religious communities is the eperception to see the difference between faith and belief. Perseption is a method of finding knowledge to understand an object of knowledge particularly (Gharawiyan 2012). Particular knowledge toward the object of knowledge will affect human behavior, because all individual will were based on his knowledge. In philosophical discourse, the role of perception is very important toward epistemology or human knowledge that always directing individual views to see object of knowledge limitedly, especially limitation to understand the structure of beliefs of religious communities (Mutahhari 2017). 
The limitation in understanding the structure of belief outside itself was the main problem that causes blaming attitude and feels that his only belief is true, is the wrong attitude in framing religiosity that trigger intolerance conflict and violence to occurred in the life of religious communities (Muhaemin and Sanusi 2019; HM, Mualimin, and Nurliana 2018). If they are not in the same faith, they will hate of those who are not in the same religion. If they are religious, then he hates those who are not religious. If they are religious, then they will hate those who are not of one mind. This kind of particular point of view will continue to happen in the cycle; so that they don't see any mistakes come from them, but toward beliefs outside themselves (Al-Hadar 2018).

All failures in understanding religiosity in the scope of religion, is the influence of perception that always mapping the object based on differences. Consequently, individual cannot see harmony in accordance with those faith and beliefs. Murtadha Muthahhari (1978) explain that perception always keep humans away from the truth, because he has rejecting all beliefs as a different reality. The attitude of rejecting all beliefs is described as an exclusivism group that always blames and feels suspicious of the danger posed by a belief outside itself.

Further, Murtadha Muthahhari mentions that particular understanding was based on the ability of human sense perceptions that sees and hears all religious information limitedly and do not want to examine the truth of the information in a comprehensive and explanative manner. As a consequence, individuals view everything particularly and rejecting the belief obtained from the information (Mutahhari 2017). The denial toward a belief based on the particular knowledge brings on exclusivism to hatred and do violence to other believers who is different with him. The attitude of violence and hatred toward believers can bring certain war and hostility in the middle of religious people which describe moral crisis (Kimball 2003).

In contemporary era, it is known that cases of violence and intolerance of religious communities are so high, as data from the National Human Rights Commision (KOMNAS HAM) and Wahid Institute. The higher number of cases violence and intolerance in religious community is based on human perception to see the differences in belief particularly obtained through some social media, such like Whatsapp, Youtube, and Instagram which cause inequality and particular paradigm in people's life. Inequality and particular paradigm encouraging the creation of hostility and mutual blame that result in persecution between religious communities (Muhaemin and Sanusi 2019).

Functionally, religion's role to unite people in the place of faith and belief, as Emile Durkheim view. Worship hall in prople's life will encourage them to achieve one understanding to create a peace, peaceful and safe life between religious communities (Durkheim 2011). Emile Durkheim view in accordance with Huston Smith (2015) who explain that every teaching will guide human to achieve perfection, because the basic concept of religion is the existence of The Most Perfect Being. The basic concept of religion is to arrange people to worship to build closeness with The Most Perfect and creating peace in the social dimension.

Based on Emile Durkheim and Huston Smith point of view, it can be known that the main function of religion is to guide human to unite toward perfection. But, in reality the perception of religious community toward the different of faith and belief in the scope of religion limit the function of religion. It is of course, the main problem is human perception who failed to understand various belief and faith outside himself, until shut himself from the true reality (Yusufian 2014). To cope with the problem of religious communities perception, author uses Mulla Sadra epistemology by reffering to his magnum opus, al-Hikmah al-Mutäliyah fì al- Asfär al-Aqliyyah al-Arba'ah. 
Mulla Sadra (2002) mention that human has two instruments of knowledge that is sense perception and reason, which must correspond each other. If reason and the five senses doesn't have correspondency, so human only gained particular knowledge, as religious communities understand in one belief limitedly. Mulla Sadra explains that correspondency between reason and sense perception are begin with basic understanding that is informations gained through the power of sense perception. Human sense perception is the first knowledge toward the object in reality. Humans sense perception will perceive object particularly analyzed by reason, to receive universal concept. Particular changes into universal is one of the role of reason to perceive object of knowledge widely (Kalin 2010).

The explanation on the instrument of knowledge according to Mulla Sadra is related with the view point of religious communities who are tend to prioritize reason and sensory perception separately, so that the understanding toward reality is particular (Sudarminta 2002). The first step to overcoming mistakes of religious community is to combine between reason and sensory perception without neglecting both roles for human knowledge. If individual optimizes the role of reason and the five senses simultaneously, so that the understanding toward faith and belief will become universal (Kartanegara 2007).

At the universal stage, human being does not only know the difference but also understand the similarity of the faith and belief in himself. Mulla Sadra view was sharpened by Murtadha Muthahhari that the different of faith and belief are also based on methodological differences in understanding religious text, so that difference is something common happen (Mutahhari 1978). Although there are differences in beliefs, Murtadha Mutahhari also do not ignore that there is similarity in the difference of faith and beliefs that cannotbe understood by religious communities. Because, religious communities are always see the different particularly in viewing the belief outside themselves as something wrong (Mutahhari 1978).

Based on Murtadha Muthahhari explanation, it can be understood that the main problem of moral crisis in the scope of religious communities is not coming from religion, but the paradigm of society understood religious teaching particularly causes many difference. Various differences imply hostility and violence among every religious believer (Muhaemin and Sanusi 2019). By reunderstanding correspondecy between reason and sensory perception in Mulla Sadra point of view, can be solution to change every failure in religious communities to understand the different which imply behavior to resect each other in every differences.

Mulla Sadra explain about the process of correlation between reasons and sensory perception in human paradigm begin with consciousness. Consciousness id the main principle of Mulla Sadra epistemology by realizing the perceptional object and perceptional knowing subject, in this case the perceptional object is various differences of faith and beliefs and the perceptional subject is religious communities (Bagus 2002). The awaereness of subject toward object will reconstruct its understanding to apprehend that the different of religious teachings are something necessary by involving the power of sense perception. The more sense perception collecting much information through discourse and preaching in social media, the more particular the conclusion gained. Mulla Sadra called particular knowledge as al-aql al-hayulla (Sadra 2002).

The results of particular sense perceptions are brought toward reason to abstract and analyze particular information to become universal concept. Universal concept affecting human will to deal with various differences in reality. Mulla Sadra said that to influence knowledge by the term aql al-malakah (Sadra 1941). Furthermore a practical knowledge on the level of al-aql al-malakah will describes the process of takhalli or the decoration of 
human existence after succeeded to release many dirty behaviors (taballi) at the level of contemplation. The process of self decoration from good-deed will be embedded in its existence, so that humans can behave either continuously or accustomed (Haidari 2011).

The habit to do good deed will affecting the actuality of practical reason or human ma'rifat al-khair on the level of al-aql al-fi'il as the basis of the perfection of theoretical reasons or ma'rifat al-haq, which are al-aql al-hayula and al-aql al-malakah (Haidari 2011). The actuality of al-aql al-fi'il in the scope of ma'rifat al-khair will affect simplicity (basith) of soul to perfecting himself in reality. Because, according to Mulla Sadra soul is the knowing substance and will in reality. All knowledge achieved in the sense perceptions and reasons are all sourced from the soul, even various human behaviors are moved by the soul (Sadra 2002).

The simplicity of soul will realized human existence that doesn't depend on lust and emotion to think and to will, so that human existence was not describe as animal, but on the level of human or rational to behave well and have universal paradigm to build harmonization between beings as the process of perfection and get closer to God without looking at various different and faith and beliefs (Sadra 1941).

Therefore, it can be understood that the teaching of Mulla Sadra's Hikmah alMuta'aliyah has the urgency to unite religious societies through individual perception. Perception is the main problem of religion in the contemporary era that always influence human knowledge to move based on desire and emotion without discusses and explores any further the root of differences in each beliefs and thought, so that it is hard to see similarities of each beliefs anf thougts outside himself. As a result, individual will reject and blame all beliefs outside himself. Correlation between reason and five senses in the right solution to overcome fallacies in religious society paradigm, in order to established harmony in social scope.

\section{CONCLUSION}

Based on the explanation above, author conclude that moral crisis that occurs in the life of religious society because of particular understanding in comprehending religion particularly. As a result, religious society refuses and blames various beliefs and thoughts outside their beliefs. The implication, each individual will limit themselves from many beliefs outside their beliefs that create discrepancy between religious societies in social frame. Various problem in religious frame are based on failures in understanding which influence their will in reality.

In philosophical civilization there are two foundation of human knowledge, which are reason and the five senses. Both foundational knowledges are always directing human being into particular and limited understanding, when there are no correspondency. This kinds of problem can be known through rational understanding that only viewing on various beliefs based on different understanding. Whereas, sensory perception always directing human to gain limited conclusion, as far as sensory perception. The limitation of reason and sensory perception will create particular and limited knowledge and understanding to comprehend the teaching of beliefs that different with individual beliefs.

It is of course, a different understanding will affect the will of individual to intolerance behaviour and reject all understanding in himself to necessitate rivalry and combat as moral crisis of religious society. Based on various problem, it can be known that the main problem of such moral crisis, that is the understanding of religious society to understand various differences particularly and limitedly. Mulla Sadra in his work Hikmah Muta'aliyah try to overcome those problem, through the correspodence of reason and the five senses as a faculty of soul knowledge. 
According to Mulla Sadra, reason and common sense must be unite so that both of them resulting universal concept which influence human behaviour to view various differences as something necessary and not only views by differences, but to understand that every teaching has similiarity and has one core of teaching, which to create peace, harmony, and safety in the life of religious society, as viewed by Huston Smith and Emile Durkheim. The creation of peace, harmony and safety in human life describes the perfection of human existence, theoretically and practically that human do not view everything based on differences and always create harmony between every single human beigs in the world. 


\section{BIBLIOGRAPHY}

Al-Farabi. 1976. Fushush Al-Hikam. Baghdad: Ma'arif.

Al-Ghazali. 1975. Ma'ārij al-Quds Fì Madārij Ma'rifat an-Nafs. Beirut: Dar Al-Afaq AlJadidah.

Al-Hadar, Husein Ja'far. 2018. Apalagi Islam Itu Kalau Bukan Cinta?! Ciputat: Yayasan Islam Cinta Indonesia.

Ali, Muhammad. 2011. Memahami Riset. Jakarta: Pustaka Cendikia Utama.

Asrori, Ahmad. 2015. 'Radikalisme Di Indonesia: Antara Historisitas Dan Antropisitas'. KALAM 9 (2): 253-68. https://doi.org/10.24042/klm.v9i2.331.

Badruzaman, Dudi. 2019. 'Perkembangan Paradigma Epistemologi dalam Filsafat Islam'. Idea : Jurnal Humaniora 2 (1): 52-64. https://doi.org/10.29313/idea.v0i0.4263.

Bagus, Lorens. 2002. Kamus Filsafat. Jakarta: Gramedia Pustaka Utama.

Bartens, K. 2005. Panorama Filsafat Modern. Jakarta: Mizan.

Bennet, Jonathan. 2001. Learning from Six Philosophers: Descartes, Spinoza, Leibniæ, Locke, Berkeley, Hume. New York: Oxford University Press.

Capoleston, Frederick. 1985. A History of Philosophy: Hobbes to Hume. New York: Bantam Doubleday Dell.

Chumaedi, Ahmad. 2018. 'Pemikiran Murtadha Muthahhari Tentang Negara dan Masyarakat serta Pandangannya terhadap Revolusi Islam Iran'. Journal of Government and Civil Society 2 (1): 33-50. https://doi.org/10.31000/jgcs.v2i1.717.

Copleston, Frederick. 1985. A History of Philosophy: Hobbes to Hume. New York: Bantam Doubleday Dell.

Durkheim, Emile. 2011. The Elementary Forms Of The Religious Life. Yogyakarta: IRCiSoD.

Eshots, Yanis. 2010. "Substantial Motion" and "New Creation" in Comparative Context'. Journal of Islamic Philosophy 6: 79-92. https://doi.org/10.5840/islamicphil201065.

Fazlurrahman. 2000. Mulla Shadra. Bandung: Mizan.

Gama, Cipta Bakti. 2018. Filsafat Jiwa: Dialektika Filsafat Islam Dan Filsafat Barat Kontemporer. Jakarta: Pustaka Sophia.

Gharawiyan, Muhsin. 2012. Pengantar Memahami Filsafat Buku Daras Filsafat Islam: Penjelasan Untuk. Mendekati Analisis Teori Filsafat Islam. Jakarta: Sadra Press.

Hadiwijono, Harun. 1980. Sari Sejarah FIlsafat Barat 2. Yogyakarta: Kanisius.

Haidari, Sayyid Kamal. 2011. Bubusul Fi 'Imi al-Nafs al-Falsafah. Tehran: Massah al-Imam alJawad Lil-Fikri wa As-tsaqafah.

Haq, Muhammad Abdul. 2013. Mulla Sadra Concept of Subtantial Motion. Islamabad: Islamic Research Institute.

Hardiman, F Budi. 2004. Filsafat Modern: Dari Machiavelli Sampai Nietzsche. Jakarta: Gramedia.

Hikam, Muhammad AS, and Stanislaus Riyanta. 2018. 'The Development of Radical Groups in Indonesia After Government Regulations in Lieu of Law No 1/2017 Concerning Community Organization and Law No 5/2018 Concerning Terorism in National Security Perspective'. Jurnal Pertahanan \& Bela Negara 8 (3): 47-68. https://doi.org/10.33172/jpbh.v8i3.448.

HM, Abubakar, Mualimin, and Nurliana. 2018. 'Elit Agama Dan Harmonisasi Sosial Di Palangkaraya'. Khazanah: Jurnal Studi Islam Dan Humaniora 16 (2): 277-96. https://doi.org/10.18592/khazanah.v16i2.2337.

Hossein, Sheykh Rezaee, and Hashemi Mohammad Mansur. 2009. 'Knowledge as A Mode of Being: Mulla Sadra's Theory of Knowledge' 6 (4): 19-42.

Kalbikani, Ali Rabbani. 1998. İdhāhu Al-Hikmah Fi Syarah Bidāyah al-Hikmah. Beirut: Dār alTiyār al-Jadīd. 
Kalin, Ibrahim. 2000. 'Knowledge as the Unity of the Intellect and the Object of Intellection in Islamic Philosophy: A Historical Survey from Plato to Mulla Sadra'. Transcendent Philosophy: An International Journal for Comparative Philosophy and Mysticism 1 (1).

2010. Knowledge in Later Islamic Philosophy: Mulla Sadra on Existence, Intellect, and Intuition. Oxford: Oxford University Press.

Kamal, Muhammad. 1988. Mulla Sadra's Trancendent Philosophy. Burlington: Ashgate Publishing.

2009. 'Rethinking Being: From Suhravardi to Mulla Sadra'. Journal of Shia Islamic Studies 2 (4). / scholarlywork/315397-rethinking-being--from-suhravardi-to-mullasadra.

Kartanegara, Mulyadi. 2007. Nalar Religius: Menyelami Hakikat Tuban, Alam, d an Manusia. Jakarta: Erlangga.

Khamaeni, Sayyed Muhammad. 2004. Mulla Sadra's Trancendent Philosophy. Tehran: SIPRIn.

Khamenei, Sayyed Muhammad. 2004. Mulla Sadra's Trancendent Philosophy. Tehran: SIPRIn.

Khatoon, Jamila. 2004. The Place of God, Man, and Universe in the Philosophic System of Iqbal. Lahore: Falcon Printing Press.

Kimball, Charles. 2003. Kala Agama Menjadi Bencana. Bandung: Mizan.

Komnas HAM. 2017. 'Laporan Tahunan Kebebasan Beragama dan Berkeyakinan 2016'. 2017. https://www.komnasham.go.id/index.php/laporan/26/laporan-tahunankebebasan-beragama-dan-berkeyakinan-2016.html.

Labib, Muhsin. 2011. Pemikiran Filsafat Ayatullah Taqi Mizbah Yazdi. Jakarta: Sadra Press.

Mandaling, Taufik. 2013. Mengenal Filsafat Lebih Dekat. Yogyakarta: Idea Press.

Marzali, Amri. 2017. 'Agama dan Kebudayaan'. Umbara 1 (1). https://doi.org/10.24198/umbara.v1i1.9604.

Miri, Sayyed Mohsen. 2005. Sang Manusia Sempurna: Antara Filsafat Islam Dan Hindu. Bandung: Teraju.

Mousavi, Ahmad Kazemi. 1999. Mullā Sadrä's Conception of Tlm and 'Ulama. Tehran: SIPRIn.

Muhaemin, Enjang, and Irfan Sanusi. 2019. 'Intoleransi Keagamaan Dalam Framing Surat Kabar Kompas'. Communicatus: Jurnal Ilmu Komunikasi 3 (1): 17-34. https://doi.org/10.15575/cjik.v3i1.5034.

Mutahhari, Murtadha. 1978. Kuliyātul Ulumūl Isläm. Qom: Sadra.

- 2017. Teori Pengetahuan: Catatan Kritis Atas Berbagai Isu Epistemology. Jakarta: Sadra Press.

Najati, Muhammad Utsman. 2002. Jiwa Dalam Pandangnan Para Filsuf. Bandung: Pustaka Hidayah.

Nur, Dimas. 2016. 'Harmoni Sosial Keagamaan TNI Di YONKAV 8 KOSTRAD BEJI Kabupaten Pasuruan'. Undergraduate Thesis, Surabaya: UIN Sunan Ampel. http://digilib.uinsby.ac.id/12736/.

Palmer, Donlad. 2001. Looking at Philosophy: The Unbearable Heaviness of Philosophy Made Lighter. New York: McGraw-Hill.

Rahmatiah, Sitti. 2018. 'Pemikiran Tentang Jiwa (Al-Nafs) Dalam Filsafat Islam'. Sulesana: Jurnal Wawasan Keislaman 11 (2). https://doi.org/10.24252/.v11i2.4538.

Reza, Gholam. 1999. The Concept and Reality of Being in Mulla Sadra. Tehran: SIPRIn.

Rezai, Muhammad. 1999. 'The Theory of the Correspondence in the Transcendent Theosophy'. In . Tehran: SPRIn.

Rizvi, Sajjad. 2009. Mulla Sadra and Metaphysics. London: Routledge.

Russell, Bertrand. 2016. Sejarah Filsafat Barat. Yogyakarta: Pustaka Pelajar. 
Sadra, Mulla. 1941. Al-Syawāhid al-Rubübiyah Fì al-Manāhij al-Sulükìyah. Qom: Markas Nasir Dānesygoh.

1984. Mafatil Al-Ghaib. Tehran: Muassasah Mutala'at Wa Tahquqat Farangi.

. 2002. Al-Hikematuh al-Mutāìyah Fì al-Asfär al-Aqliyah al-Arba'a. Beirut: Dār al-Ehia al-Tourath al-Arabi.

Saputra, Happy. 2016. 'Konsep Epistemologi Mulla Shadra'. SUBSTANTLA: Jurnal IlmuIlmu Ushuluddin 18 (2): 183-96. https://doi.org/10.22373/subtantia.v18i2.3005.

Sholihan, Sholihan. 2010. 'Al-Hikmah Al-Muta'Âliyyah Pemikiran Metafisika Eksistensialistik Mulla Shadra’. Ulumuna 14 (1): 21-38. https://doi.org/10.20414/ujis.v14i1.226.

Sina, Ibn. 1952. Ahwal Al-Nafs. Kairo: Dar Ihya' al-Kutub al-Arabiyah.

-1960. Al-Isyāräti Wa al-Tanbihat. Kairo: Dar Al-Maarif. 1998. Al-Mabdā Wa al-Ma'ād. Tehran: Tehran Universitas Press.

Smith, Huston. 2015. Agama-Agama Manusia. Jakarta: Serambi.

Sudarminta, Jujun. 2002. Epistemologi Dasar: Pengantar Filsafat Pengetahuan. Yogyakarta: Kanisius.

Thabathabai, Sayyed Hossein. 1997. Bidāyah Al-Hikmah. Qom: Muassah al-Mārif alIslāmiyyah.

2000. Nihāyah Al-Hikmah. Qom: Muassah al-Nasri al-Islāmī.

- 2011. Ushul Al-Falsafah. Beirut: Beirut: Dār al-Jawād Imam.

Wahid Institute. 2016. Ringkasan Eksekutif Laporan Tabunan Kemerdekaan Beragama Berkeyakinan (KBB) Di Indonesia. Jakarta: Wahid Foundation.

Walid, Kholid. 2012. Perjalanan Jiwa Menuju Akbirat: Filsafat Eskatologi Mulla Sadra. Jakarta: Sadra Press.

Yusufian, Hasan. 2014. Kalam Jadid: Pendekatan Baru Dalam Isu-Isu Agama. Jakarta: Sadra Press. 